\title{
Regarding: "The effect of omega-3 fatty acid supplementation on clinical and biochemical parameters of critically ill patients with COVID-19: a randomized clinical trial"
}

\author{
Takeshi Nakata ${ }^{1,3^{*}}$ (i), Takashi Ariie ${ }^{2,3}$ and Shunsuke Taito ${ }^{3,4}$
}

To the Editor,

We read the article "The effect of omega-3 fatty acid supplementation on clinical and biochemical parameters of critically ill patients with COVID-19: a randomized clinical trial" with very interest [1]. We agree that omega-3 polyunsaturated fatty acid (n3-PUFA) supplementation has some clinical benefits. However, we have two methodological concerns, which may alter the conclusion.

First, this study has a high risk of bias for selection of the reporting results [2]. The authors mentioned the effectiveness of n3-PUFAs for treating metabolic acidosis and enhancing renal function, although these outcomes were not specified as the primary outcomes in the protocol [3]. In addition, the sample size of this study and that calculated in protocol were quite different. This point is important because with a small sample size, the possibility that the results were attributable to chance or bias cannot be excluded, and it is unclear whether the study was adequately powered. Therefore, the authors should provide the information regarding the primary outcome which was used for calculating the sample size and the

This comment refers to the article available online at https://doi.org/10.1186/ s12967-021-02795-5.

\footnotetext{
*Correspondence: nakata@oita-u.ac.jp

${ }^{1}$ Department of Endocrinology Metabolism, Rheumatology

and Nephrology, Faculty of Medicine, Oita University, 1-1 Idaigaoka,

Hasama-machi Yufu, Oita 879-5593, Japan

Full list of author information is available at the end of the article
}

magnitude of the difference that the study was designed to detect. These data would provide readers with a better understanding of the study.

Second, n3-PUFAs might not improve the outcome two weeks after the start of the intervention. All-cause mortality is one of the critical outcomes reported by the Core Outcome Set for Clinical Trials on Coronavirus Disease 2019 [4]. Although the authors emphasized the better results of the 1-month survival in the intervention group, the mortality at the end of 2-week treatment period was much higher in the intervention group than that of the control group (16.7\% vs $9.6 \%)$. As the authors presented laboratory data collected at the end of 2 weeks of treatment, the 2-week mortality should be mentioned. Additionally, in general the results of per protocol analyses sometimes make the intervention appear to be more effective than the results of intention-to-treat analyses [5]. So, the results of a modified intention-to-treat analysis which includes data on the participants who withdrew after randomization (because of no indication for enteral feeding), the results might provide more useful knowledge for clinicians to evaluate the true effects of $\mathrm{n} 3$-PUFAs in an actual clinical setting.

\section{Authors' contributions \\ TN wrote the main manuscript. TA and ST revised the manuscript. All authors read and approved the final manuscript. \\ Funding \\ Not applicable.}

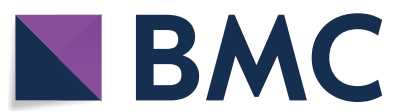

c) The Author(s) 2021. This article is licensed under a Creative Commons Attribution 4.0 International License, which permits use, sharing, adaptation, distribution and reproduction in any medium or format, as long as you give appropriate credit to the original author(s) and the source, provide a link to the Creative Commons licence, and indicate if changes were made. The images or other third party material in this article are included in the article's Creative Commons licence, unless indicated otherwise in a credit line to the material. If material is not included in the article's Creative Commons licence and your intended use is not permitted by statutory regulation or exceeds the permitted use, you will need to obtain permission directly from the copyright holder. To view a copy of this licence, visit http://creativeco mmons.org/licenses/by/4.0/. The Creative Commons Public Domain Dedication waiver (http://creativecommons.org/publicdomain/ zero/1.0/) applies to the data made available in this article, unless otherwise stated in a credit line to the data. 
Availability of data and materials

Not applicable.

\section{Declarations}

Ethics approval and consent to participate

Not applicable.

\section{Consent for publication}

Not applicable.

\section{Competing interests}

The authors declare that they have no conflicts of interests.

\section{Author details}

'Department of Endocrinology Metabolism, Rheumatology and Nephrology, Faculty of Medicine, Oita University, 1-1 Idaigaoka, Hasama-machi Yufu, Oita 879-5593, Japan. ${ }^{2}$ Department of Physical Therapy, School of Health Sciences at Fukuoka, International University of Health and Welfare, 137-1 Enokizu, Okawa-shi, Fukuoka 831-8501, Japan. ${ }^{3}$ Systematic Review Workshop Peer Support Group (SRWS-PSG), Osaka, Japan. ${ }^{4}$ Division of Rehabilitation, Department of Clinical Practice and Support, Hiroshima University Hospital, Kasumi 1-2-3, Minami-ku, Hiroshima 734-8551, Japan.

Received: 9 June 2021 Accepted: 18 June 2021

Published online: 30 June 2021

\section{References}

1. Doaei S, Gholami S, Rastgoo S, Gholamalizadeh M, Bourbour F, Bagheri $\mathrm{SE}$, et al. The effect of omega-3 fatty acid supplementation on clinical and biochemical parameters of critically ill patients with COVID-19: a randomized clinical trial. J Transl Med. 2021:19:128.

2. Cochrane Training Handbook. Chapter 8. Assessing risk of bias in a randomized trial. Section 8.7. Bias in selection of the reported result https://training.cochrane.org/handbook/current/chapter-08\#section-8-7. Accessed May 25, 2021.

3. Iranian Registry of Clinical Trials. Trial registration number: IRCT20151226025699N3; https://en.irct.ir/trial/48213. Accessed 23 May 2021.

4. Jin X, Pang B, Zhang J, Liu Q, Yang Z, Feng J, et al. Core outcome set for clinical trials on coronavirus disease 2019 (COS-COVID). Engineering (Beijing). 2020;6:1147-52.

5. Brittain E, Lin D. A comparison of intent-to-treat and per-protocol results in antibiotic non-inferiority trials. Stat Med. 2005;24:1-10.

\section{Publisher's Note}

Springer Nature remains neutral with regard to jurisdictional claims in published maps and institutional affiliations.
Ready to submit your research? Choose BMC and benefit from:

- fast, convenient online submission

- thorough peer review by experienced researchers in your field

- rapid publication on acceptance

- support for research data, including large and complex data types

- gold Open Access which fosters wider collaboration and increased citations

- maximum visibility for your research: over 100M website views per year

At BMC, research is always in progress.

Learn more biomedcentral.com/submissions 